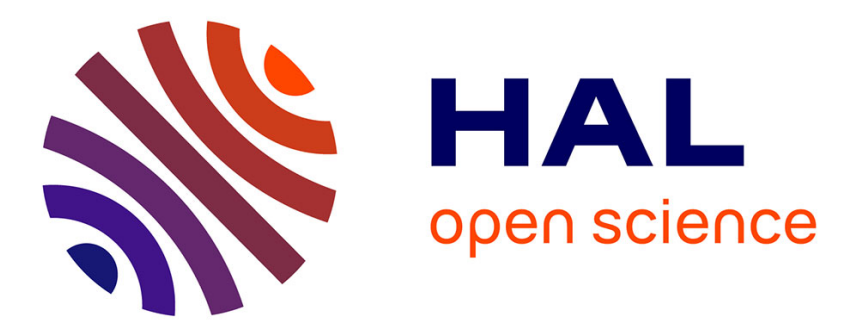

\title{
Can clodronate be effective in the treatment of disabling hydroxyapatite crystal-deposition disease? A report of two cases
}

\author{
Gianantonio Saviola, Lul Abdi-Ali, Paola Baiardi, Maurizio Benucci
}

\section{To cite this version:}

Gianantonio Saviola, Lul Abdi-Ali, Paola Baiardi, Maurizio Benucci. Can clodronate be effective in the treatment of disabling hydroxyapatite crystal-deposition disease? A report of two cases. Rheumatology International, 2010, 31 (3), pp.415-417. 10.1007/s00296-010-1575-2 . hal-00612023

\section{HAL Id: hal-00612023 \\ https://hal.science/hal-00612023}

Submitted on 28 Jul 2011

HAL is a multi-disciplinary open access archive for the deposit and dissemination of scientific research documents, whether they are published or not. The documents may come from teaching and research institutions in France or abroad, or from public or private research centers.
L'archive ouverte pluridisciplinaire $\mathbf{H A L}$, est destinée au dépôt et à la diffusion de documents scientifiques de niveau recherche, publiés ou non, émanant des établissements d'enseignement et de recherche français ou étrangers, des laboratoires publics ou privés. 


\section{CAN CLODRONATE BE EFFECTIVE IN THE TREATMENT OF DISABLING HYDROXYAPATITE CRYSTAL DEPOSITION DISEASE ? - A REPORT OF TWO CASES .}

\section{Gianantonio Saviola MD (1)}

Lul Abdi Ali MD (1)

Paola Baiardi PhD (2)

\section{Maurizio Benucci MD (3)}

(1) Salvatore Maugeri Foundation IRRCS, Rheumatology and Rehabilitation Unit, Castel Goffredo, Mantua, Italy.

(2) Salvatore Maugeri Foundation IRCCS and University of Pavia, Methodology Unit, Consorzio Valutazioni Biologiche e Farmacologiche, Pavia, Italy.

(3) New Hospital San Giovanni di Dio, Azienda Sanitaria Fiorentina, Rheumatology Unit, Florence, Italy.

\section{Corresponding author: Dr Gianantonio Saviola, Salvatore Maugeri Foundation IRCCS, Rheumatology and Rehabilitation Unit, 46042, Castel Goffredo, Mantua, Italy; phone 0376 774771, fax 0376779886 e-mail adress: gianantonio.saviola@fsm.it \\ SUMMARY : Hydroxyapatite crystals are often deposited in the vicinity of joints, where they can cause a clinical periarthritis. Clodronate is a first generation bisphosphonate which has the ability to reduce ectopic calcifications. \\ Two women were affected by disabling calcific periarthritis of the shoulders lasting for years and resistant to any traditional drug (including glucocorticoids), infiltration and surgical treatment. We treated both patients with low-dose methylprednisolone added to intramuscular clodronate at the daily dose of $100 \mathrm{mg}$ administered for 20 days every 3 months for 5 cycles (18 months). \\ In both cases the results were clinically evident within 1 month, showing a significant reduction of pain and disability. After 18 months the result was furthermore radiologically evident in both cases with a great reduction in the size of calcifications. These improvements were still present at follow-up after 7 and 5 years respectively with complete functional recovery.}

KEY WORDS: clodronate, bisphosphonates, periarthritis of the shoulder, ectopic calcification, hydroxyapatite crystal deposition disease, HADD.

\section{ABBREVIATIONS:}

HA Hydroxyapatite

\section{CLO Clodronate}

BP Bisphosphonate

HADD Hydroxyapatite crystal deposition disease

\section{GC Glucocorticoids}

MP 6-methylprednisolone

im intramuscular

iv intravenous

\section{CASE REPORT N¹}

A woman, began suffering from bilateral shoulder calcific periarthritis at the age of 35 , treated with several anti-inflammatory drugs, including high-dose GC per os and intra-articular GC. Nevertheless she developed a right "frozen shoulder" and underwent surgical treatment of irrigation in arthroscopy with no 
results. At the age of 44 the plane X-ray of the shoulders showed bilateral coarse calcifications which reached $3 \mathrm{~cm}$ in diameter on the right hand side.

We diagnosed an Hydroxyhapatite crystal-deposition disease (HADD). We treated her with low- dose GC (MP [4 mg) added to a cycle of intramuscular clodronate (Clasteon ${ }^{\circledR}$, Abiogen Pharma, Pisa, Italy) 100 mg daily for 20 days. Within 30 days the pain and disability disappeared and the patient's health greatly improved. The treatment continued with complete success for 18 months with MP $2 \mathrm{mg}$ daily added to CLO $100 \mathrm{mg}$ im for 20 days every 3 months. At the end of this period a new plane $\mathrm{x}$-ray of the right shoulder showed a great reduction in the size of the calcification from 3 to $1 \mathrm{~cm}$ in diameter (Fig.1). The treatment with low-dose MP ( $2 \mathrm{mg}$ daily) was then continued. In the next 7 years of follow-up the patient had no relapse, could work and do sports without any problem. A further plane x-ray demonstrated that calcification at the right shoulder still maintains the small size $(1 \mathrm{~cm})$.

\section{CASE REPORT $\mathrm{N}^{\circ} 2$}

A woman began suffering from bilateral calcific shoulder periarthritis at the age of 30 . She was treated with antinflammatory drugs and intra-articular glucocorticoids obtaining only partial and temporary amelioration. At the age of 54 the left shoulder was affected by a disabling pain resistant to any traditional therapy .

A plane-x-ray of the left shoulder showed a calcification with a diameter of $12 \mathrm{~mm}$. We diagnosed an HADD and we treated her with low- dose GC (MP $2 \mathrm{mg}$ ) added to im clodronate (Clasteon $\AA$, Abiogen Pharma, Pisa, Italy) $100 \mathrm{mg}$ daily for 20 days. Within 30 days the pain and disability disappeared and the patient's health improved greatly. The treatment continued with complete success for 18 months with MP 2 mg daily added to CLO $100 \mathrm{mg}$ im for 20 days every 3 months. At the end of this period a new plane $\mathrm{x}$-ray of the left shoulder showed a great reduction in the size of the calcification (from 12 to $5 \mathrm{~mm}$ in diameter) (fig. 2). The treatment with low-dose MP ( $2 \mathrm{mg}$ daily) was then continued. In the next 5 years of follow-up the patient had no relapse and could work without any problem. A further plane x-ray demonstrated that calcification at the left shoulder still maintains the small size $(5 \mathrm{~mm})$.

DISCUSSION : The main characteristics and outcomes of the patients are shown in table 1.

HADD was identified as a new arthropathy in 1976 by Dieppe who recognized it as a third type of crystaldeposition disease [1]. HA crystals are a very common cause of periarticular disease giving rise to acute inflammation of tendons, intervertebral discs, joint capsules, synovium and cartilage [2, 3]. The shoulder is the most common joint involved in HADD. Clinical symptoms are often represented by chronic pain and restricted joint motion [4].

Calcifying periarthritis is found in about $3 \%$ of adult patients and in up to $17 \%$ of painful shoulder syndromes. Rupture of the crystal deposit into the next subacromial bursa is usually followed by an acute disabling pain attack with important reduction of the range of motion. Sometimes crystal deposits may persist for years leading to a chronic shoulder pain probably due to an impingement mechanism. Surgical treatments include the break of the calcifications or the percutaneous needle aspiration followed by a lavage [5].

BPs were used primarily as inhibitors of calcifications and resorption. They are able to bind to HA crystals thus inhibiting crystal growth [6]. CLO is a first generation non-nitrogen-containing BP also 
available in ampoules for im and iv injections. CLO is currently registered for the treatment of postmenopausal osteoporosis, multiple myeloma, primary hyperparathyroidism and cancer osteolysis. Each BP in vitro has a different kinetic binding affinity for HA, attributed to differences in the R2 side chain. These characteristics can explain some of BPs clinical activities [7].

CLO has a low antiresorptive potency but can be able to inhibit nonskeletal and soft tissues calcifications in both experimental models and in humans [8]. Moreover BPs, and particularly CLO have been successfully studied to prevent the development of experimental atherosclerosis, because of the ability of CLO to remove calcium from atheromatous lesions [8,9]. This property is probably linked to CLO's low affinity for bone and HA. In fact, risedronate, which has the same low affinity for bone and HA crystals, can prevent ectopic calcifications in rheumatic patients affected by CREST syndrome [10]. IN CONCLUSION: CLO could be an effective drug in the treatment of HADD reducing the size of calcifications with significant clinical improvement: the association with other drugs, as low-dose GC, could help maintaining results even in unresponsive cases.

The Authors declare no conflict of interest.

\section{REFERENCES}

1) Dieppe PA, Crocker P, Huskisson EC, Willoughby DA. Apatite deposition disease. A new arthropathy. Lancet 1976;1: 266-9.

2)Bonavita JA, Dalinka MK, Schumacher HR jr. Hydroxyapatite deposition disease. Radiology 1980;134:621-5.

3) McCarty GM: Crystal related arthropathies. In Klippel JH, Dieppe PA (Eds): Rheumatology, second edition, London, Mosby 1998; section 8.

4) Garcia GM, McCord GC, Kumar R. Hydroxyapatite crystal deposition disease. Seminar Musculoskelet Radiol 2003;7:187-93.

5) Pfister J, Gerber H. Chronic calcifying tendinitis of the shoulder-therapy by percutaneous needle aspiration and lavage: a prospective open study of 62 sholuders. Clin Rheumatol 1997; 16:269-74.

6) Fleisch H. Bisphosphonates: mechanism of action. Endocr Rev1998;19:80-100.

7) Nancollas GH, Tang R, Phipps RJ, Henneman Z, Gulde S, Wu W et al. Novel insight into actions of bisphosphonates on bone: differences in interactions with hydroxyapatite. Bone 2006;38:617-27.

8) Bevilacqua M, Dominguez LJ, Rosini S, Barbagallo M. Bisphosphonates and atherosclerosis: why? Lupus, 2005;14:1-7. 
9) Ylitalo R, Syvala $H$, Touhimaa $P$, Ylitalo $P$. Suppression of immunoreactive macrophages in atheromatous lesions of rabbits by clodronate. Pharmacology \& Toxicology, 2002; 90:139-143.

10) Fujii $N$, Hamano $T$, Isaka $Y$, Ito $T$, Imai $E$. Risedronate : a possible treatment for extraosseous calcification. Clin Calcium, 2005;15 S1:75-8.

\begin{tabular}{|c|c|c|c|c|c|c|c|c|c|}
\hline case & sex & age & $\begin{array}{l}\text { Disease } \\
\text { duration } \\
\text { (years) }^{*}\end{array}$ & $\begin{array}{l}\text { Previous } \\
\text { ineffective } \\
\text { surgical } \\
\text { treatments }\end{array}$ & $\begin{array}{l}\text { Previous } \\
\text { ineffective } \\
\text { GC infiltrations }\end{array}$ & $\begin{array}{l}\text { Previous ineffective } \\
\text { pharmacological } \\
\text { treatments }\end{array}$ & $\begin{array}{l}\text { Efficacious } \\
\text { treatment }\end{array}$ & $\begin{array}{l}\text { Change in } \\
\text { calcification size } \\
\text { within } 18 \text { months }\end{array}$ & Follow-up \\
\hline 1 & $f$ & 44 & 9 & yes & yes & $\begin{array}{l}\text { NSAIDs } \\
\text { high-dose GC }\end{array}$ & $\begin{array}{l}\text { CLO } 100 \mathrm{mg} \mathrm{im} \\
\text { daily for } 20 \text { days ( } 5 \\
\text { cycles) } \\
\text { MP 4-2 } \mathrm{mg}\end{array}$ & $\begin{array}{l}\text { From } 30 \text { to } 10 \\
\mathrm{~mm} \text { in diameter } \\
\text { (right shoulder) }\end{array}$ & 7 years \\
\hline 2 & f & 54 & 24 & no & yes & $\begin{array}{l}\text { NSAIDs } \\
\text { high-dose GC }\end{array}$ & $\begin{array}{l}\text { CLO } 100 \mathrm{mg} \mathrm{im} \\
\text { daily for } 20 \text { days ( } 5 \\
\text { cycles) } \\
\text { MP } 2 \mathrm{mg}\end{array}$ & $\begin{array}{l}\text { From } 12 \text { to } \\
5 \mathrm{~mm} \text { in diameter } \\
\text { (left shoulder) }\end{array}$ & 5 years \\
\hline
\end{tabular}

TABLE 1: Baseline characteristics and outcomes of the two reported patients.

*Disease duration is measured from the beginning of the disease to the start of the treatment with clodronate. 
Fig. 1: case $n^{\circ} 1$. Plane $x$-ray of the right shoulder at the baseline (on the left side) compared with the same shoulder after the treatment with clodronate. 


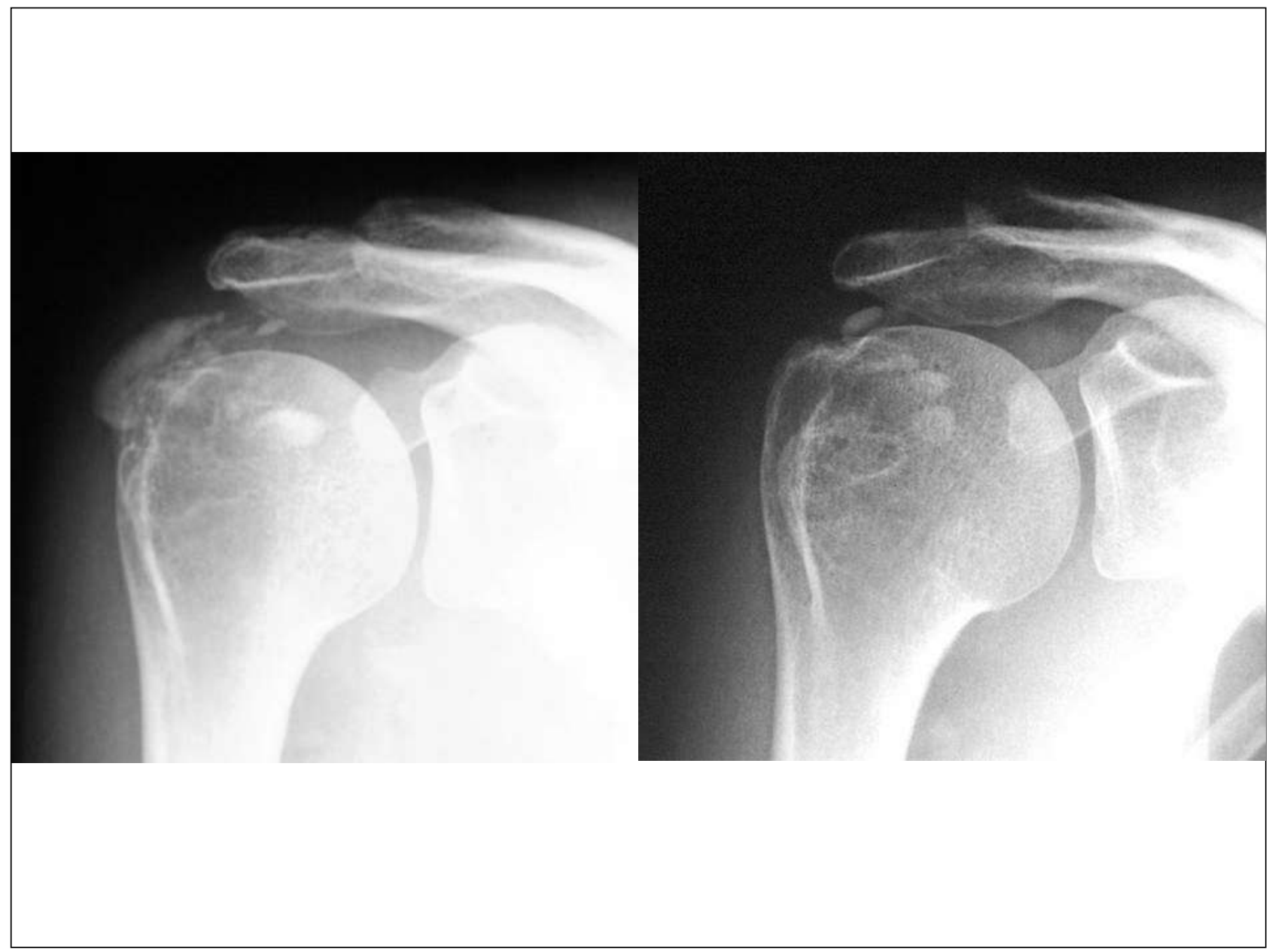

Fig. 2: case $n^{\circ} 2$. Plane $x$-ray of the left shoulder at the baseline (on the left side) compared with the same shoulder after the treatment with clodronate. 


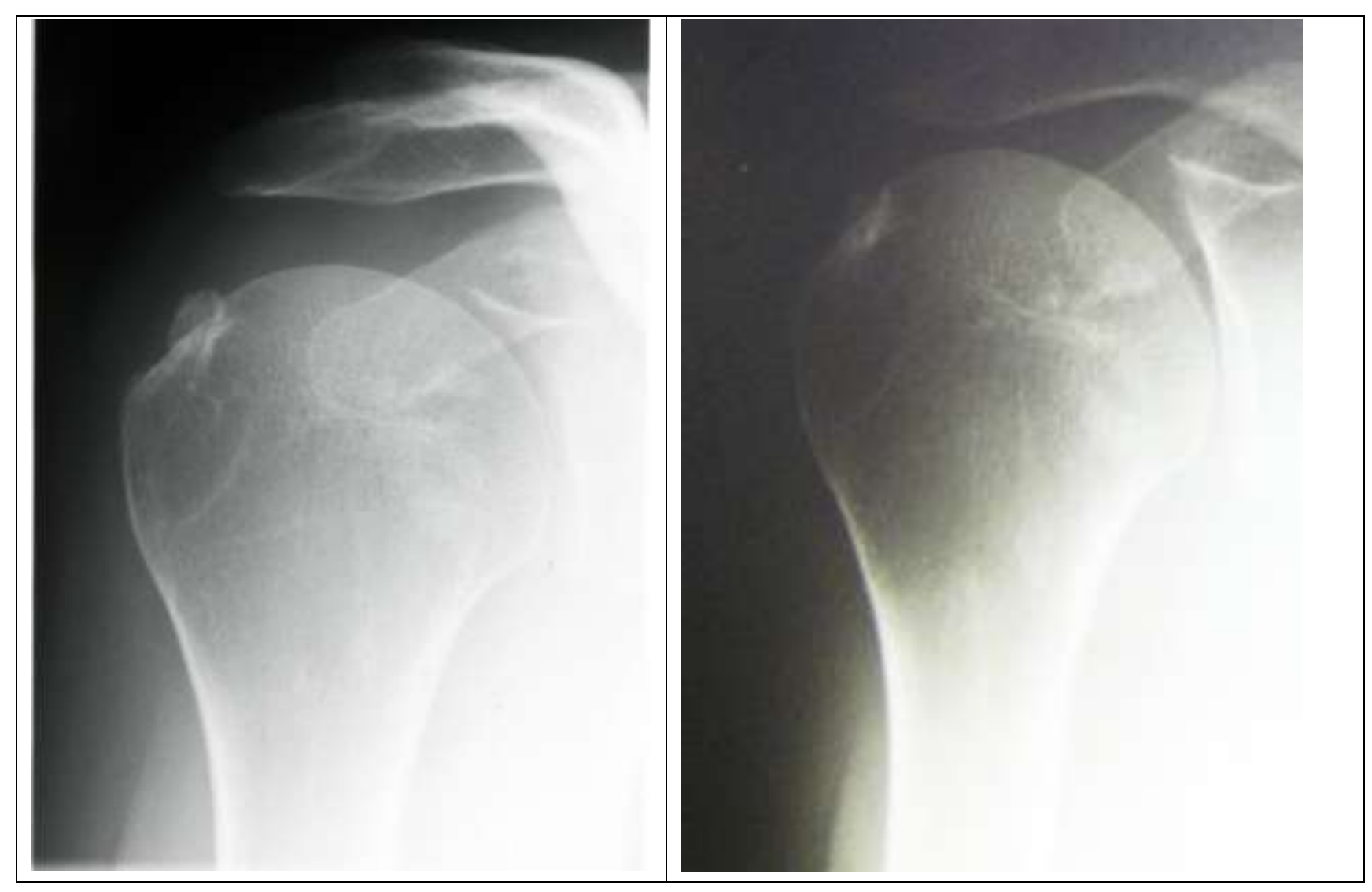

